\title{
Archaeology and Religion in Late Bronze Age Canaan
}

\author{
Aaron Greener
}

W.F. Albright Institute of Archaeological Research in Jerusalem, Salah e-Din St 26, 91190 Jerusalem, Israel; aaron@aiar.org

Received: 28 February 2019; Accepted: 2 April 2019; Published: 9 April 2019

\begin{abstract}
Dozens of temples were excavated in the Canaanite city-states of the Late Bronze Age. These temples were the focal points for the Canaanites' cultic activities, mainly sacrifices and ceremonial feasting. Numerous poetic and ritual texts from the contemporary city of Ugarit reveal the rich pantheon of Canaanite gods and goddesses which were worshiped by the Canaanites. Archaeological remains of these rites include burnt animal bones and many other cultic items, such as figurines and votive vessels, which were discovered within the temples and sanctuaries. These demonstrate the diverse and receptive character of the Canaanite religion and ritual practices. It seems that the increased Egyptian presence in Canaan towards the end of the period had an influence on the local belief system and rituals in some areas, a fact which is demonstrated by the syncretic architectural plans of several of the temples, as well as by glyptic and votive items. Late Bronze Age religious and cultic practices have attracted much attention from Biblical scholars and researchers of the religion of Ancient Israel who are searching for the similarities and influences between the Late Bronze Age and the following Iron Age.
\end{abstract}

Keywords: Late Bronze Age; Canaan; religion; cult; temples; Egypt

\section{Introduction}

Numerous excavations and a fairly large number of contemporary written documents give us a good picture of the religious system and cult practices in Canaan ${ }^{1}$ during the Late Bronze Age (ca. 1600-1180 BCE). Most of this period was characterized by an Egyptian dominance and influence over large parts of the Southern Levant, and though not a significant core area, Canaan served as a cultural and commercial crossroads of the region that was essential to Egyptian strategic and economic goals in the area. The study of the extensive Amarna archive discovered in Egypt ${ }^{2}$ teaches us that during the fourteenth century BCE, Canaan was divided into c. 20 major city-states. These city-states were independent territorial units held by a local ruler who inherited his status from his ancestors and was recognized by the Egyptian authorities, who provided for his protection and well-being. Some have suggested (see below) that the interaction between the Canaanite and Egyptian cultures may have influenced the cult practices in Canaan, especially during the end of the period, when the Egyptians increased their physical presence in the region.

1 The term "Canaan" is a geopolitical entity that includes Israel, Jordan, the West Bank and the Gaza Strip, Lebanon, and southern Syria. It is possible to identify, archaeologically speaking, a second-millennium material culture in this region that has many features in common. The term "Canaanites" does not represent an ethnic entity, but rather a group of people who share a common culture and live within a region that was defined by others as "Canaan". The geographic area studied here is somewhat more restricted than the general Canaanite area described above, and includes sites within the modern state of Israel, as well as in the Palestinian Authority.

2 This archive contained a collection of hundreds of cuneiform tablets that testify to the wide-ranging international commerce and political networks which existed during the period (e.g., Bunimovitz 1995; Moran 1992, p. 124; Finkelstein 1996; Goren et al. 2004). 
The paper will begin by presenting a background on Canaanite religion and cultic activities based on texts of the period. Following the textual background, I will move on to describe Late Bronze Age archaeological finds which are related to cult activities-mainly temples and other smaller religious paraphernalia. The paper will end with a short summary of our current understanding pertaining to the Canaanite religion and cult during the Late Bronze Age.

\section{Ugaritic Texts: Religion, Cult Practices, and Rituals}

\subsection{Canaanite Pantheon}

The excavations at Ugarit on the Mediterranean coast of Syria, have revealed a vast metropolis of the Late Bronze Age (e.g., Yon 2006). The destruction of Ugarit in the late thirteenth century BCE resulted in the preservation of an important archive of poetic (mythological and epic) and ritual texts which illuminates many aspects of religion in this Late Bronze Age city (e.g., Hess 2007, p. 97). Although one must be cautious not to equate Ugaritic religion with Canaanite religion, they both shared West Semitic elements of religion, architecture, language, and material culture. Furthermore, the Ugaritic texts contain mythological and cultic information that is closely related to that of Canaan (Hess 2007, p. 95; Alpert-Nakhai 2001, p. 41; Smith 2001, pp. 14-18). It seems that there was a rather broad cultural continuum. ${ }^{3}$

The emphasis in the Ugaritic ritual texts was on the major components of religious rites and particularly on animal sacrifice (see below). Additional texts from thirteenth-century BCE Emar (northern Syria) describe in detail rituals of priestly installation and of festivals celebrated throughout the cultic year. The Canaanite religion was polytheistic. The deities listed below are the major ones mentioned in the Ugaritic and additional local texts, though various others were worshipped alongside them. By one account, there are 240 divine names and epithets found at Ugarit. ${ }^{4}$ It seems that there were tiers of deities: the highest level was occupied by El and his consort Athirat/Ashera; the second level by their children, the divine assembly; the third level by craftsmen and trader deities; and the fourth level by minor deities such as messenger gods.

Nevertheless, it was El, creator of earth and man, who was the chief god, and the begetter of the gods (seventy in number). He bore the title "Father of Years" and is described as being wise and kind, with gray hair. He lived at the source of the rivers amid the springs of the two oceans. Athirat, mother of the gods, was El's consort. Her title was "Lady Athirat of the Sea". She was sometimes called Qds in Ugaritic texts and was depicted in Egypt in the nude with a Hathor wig (similar depictions in Canaan may also represent Athirat). She gave birth to the gods Shachar (dawn) and Shalem (dusk). It seems they both represent Venus, one at dawn and the other at dusk.

Although El was the chief god, Ba'al Hadad (meaning Lord of Thunder) was the most active. He was the "bringer of the rain" and was called "rider of the clouds". He also controlled thunder and lightning. Several of the texts from Ugarit are known as the Ba'al cycle. The first is his conflict with the sea god, Yamm. The second describes the building of his temple or palace. The third and last is his struggle with death $(m o t)$, in which he died and then rose again. Some scholars maintain that El and Ba'al were in conflict. However, the evidence that El appointed Ba'al king, and then showed remorse at Ba'al's death and rejoiced at his resurrection, leads to the opposite conclusion, although there were occasional tensions.

The god Dagon (Lord of the grain) also sometimes appears as Ba'al's father. It is possible that El was Ba'al's grandfather and Dagon his father, since he is put between the two in the Ugaritic Pantheon. Dagon is a god of minor importance and appears only in sacrificial lists and not in mythological texts.

3 Similar practices are reflected in the Biblical texts, but given their relatively late date and apologetic nature, specific Biblical passages are unhelpful in elucidating Canaanite cult practices and religion (e.g., Cross 1998 and Smith 2007).

4 The descriptions of the Canaanite deities are summarized from (Day 1992 and Van der Toorn et al. 1999). 
Ba'al's main consort was the goddess Anat, who was devoted to him. She cut up Mot, who killed Ba'al. She also defeated the multi-headed dragon (leviathan). However, the goddess Astarte is also mentioned in Ugarit as Ba'al's consort, although she is less prominent than Anat. Astarte is associated with feline imagery. To make things more complicated, the deities Athirat and Astarte, distinct in some contexts, are sometimes identified with each other.

Although Mot is the primary deity associated with the underworld at Ugarit, there were several other gods connected with the underworld. One was the god Reshef, who was the god of plague and pestilence. He is equated at Ugarit with the plague god Nergal. He is the porter of the sun goddess at the time of her setting. Molech is also an underworld deity, often associated with human sacrifice. The sun was worshipped as a goddess-Sps. She scorched the earth while Ba'al stayed in the underworld. The moon god, Yarikh, does not play a major role in Canaanite mythology, but its name is preserved in places such as Beit Yarikh and Jericho.

\subsection{Cult Practices and Rituals}

The act of slaughter and the sacrifice of live animals lay at the emotional core of many early religions. Ancient sacrifice originated from the need to sanctify the consumption of animal flesh, because the spilling of animal blood was an act of violence that required divine sanction (e.g., Alpert-Nakhai 2001, p. 40). Indeed, examination of the ritual texts from Ugarit demonstrates that overall, sacrifice was the primary ritual in ancient Near East religion and was an essential part of Canaanite worship (see also below). In fact, the principal category of cultic vocabulary was that of sacrifice (Alpert-Nakhai 2001, p. 39), which the Canaanites considered as food for the gods. Royal success required the complicity of the divine, which was asked for and acknowledged through the gesture of offerings. Sacrificial liturgies most often included a list of offerings specifying the divine recipients. Alpert-Nakhai (2001, pp. 42-44) wrote that along with livestock, agricultural products (especially oils, vegetables, and grains) were offered. From the perspective of the royal center, sacrifice was not an act of individual piety, but rather a function of the social group. Kings undertook the expense and the responsibility of sacrifice in order to promote their relationship with their patron gods, and to ensure that their city and its inhabitants were favored. The loss incurred by offering sacrifices was compensated for by the overall gain in societal well-being. Animals were also slaughtered and placed (complete or parts only) within tombs of the period (Lev-Tov and Maher 2001).

Some have argued that the evidence from Ugaritic texts demonstrates that Canaanite culture preserved ideas about personal, moral, and religious guilt for sin. Expiation could be obtained from the divine world through animal sacrifices (Hess 2007, pp. 104-6). Burnt offerings were used to attract the deity to the temple, while the "peace of fellowship" offerings functioned as a gift of greeting that the worshiper presented in the courtyard of the temple. Although not found in Ugarit, evidence of human sacrifice from the later Phoenician world may teach us about such rituals in the Canaanite world as well, especially in connection with the Canaanite god Molech.

Besides sacrifices, prayer was a means to communicate with the gods (e.g., Day 1992). The Canaanites believed in an afterlife and funerary liturgies are known in the mythological texts, with lamentations, rites, and curse formulas for disturbing the dead. The term Rephaim refers to the shades of the dead. Ugaritic kings were thought of as divine after their death and possibly even while they ruled. The Marzeah festival was an assembly comprising members from a higher economic class who celebrated a festival with a banquet (Hess 2007, p. 110-11). These ceremonies had legal sanction; met in cities and villages for drinking; could involve substantial money, including the leasing of houses and vineyards; possessed a defined membership; continued for generations; and often had a patron deity. Other rituals which were practiced by the Canaanites included sacred prostitution and the reading of animal livers-hepatoscopy (e.g., Van der Toorn et al. 1999).

At Ugarit, cultic personnel (including a variety of titled figures such as high priests, priests, and servants) were royal dependents and the needs of the temples were mostly supplied by the royal treasury (Alpert-Nakhai 2001, p. 123). However, it is certainly possible that worship was 
also a localized affair, with open-air sanctuaries or even simple household shrines serving most ordinary people in everyday practice. Anyone could build an altar, plant a sacred tree, erect a stela, or offer sacrifices. The most prominent rituals were simply the frequent presentation of food and drink offerings.

\section{Temples}

The Ugaritic texts mentioned above permit speculation about material remains from sacrificial rites that might be found in the excavation of Canaanite temples. Indeed, in this section, we will turn to evidence presented by archaeological data and investigate the remains of sacred structures and installations, and of cultic paraphernalia (see Figure 1 for a map of the sites mentioned in the text). During this period, cult centers in Canaan flourished and temples and altars were the primary bearer of religious traditions for the various city-states. In fact, Faust (2010, p. 26; and see also Faust 2019 in this issue) wrote that despite the limited archaeological exposure, over the years, more than 20 Late Bronze Age temples have been unearthed in the southern Levant, making it clear that during this period, temples were common and widespread. He argued that there was at least one temple in each settlement (including relatively small settlements), and in some cases, there was more than one such structure at a single site. Furthermore, several temples have been unearthed outside settlements (e.g., the Fosse Temple at Lachish and the 'Amman airport temple [below]), providing additional evidence for the widespread distribution of temples in this era. Faust (2010, p. 27; Faust 2019 in this issue) further suggested that temples were prevalent in rural settings, and there was probably a temple or cultic building in every Canaanite village.

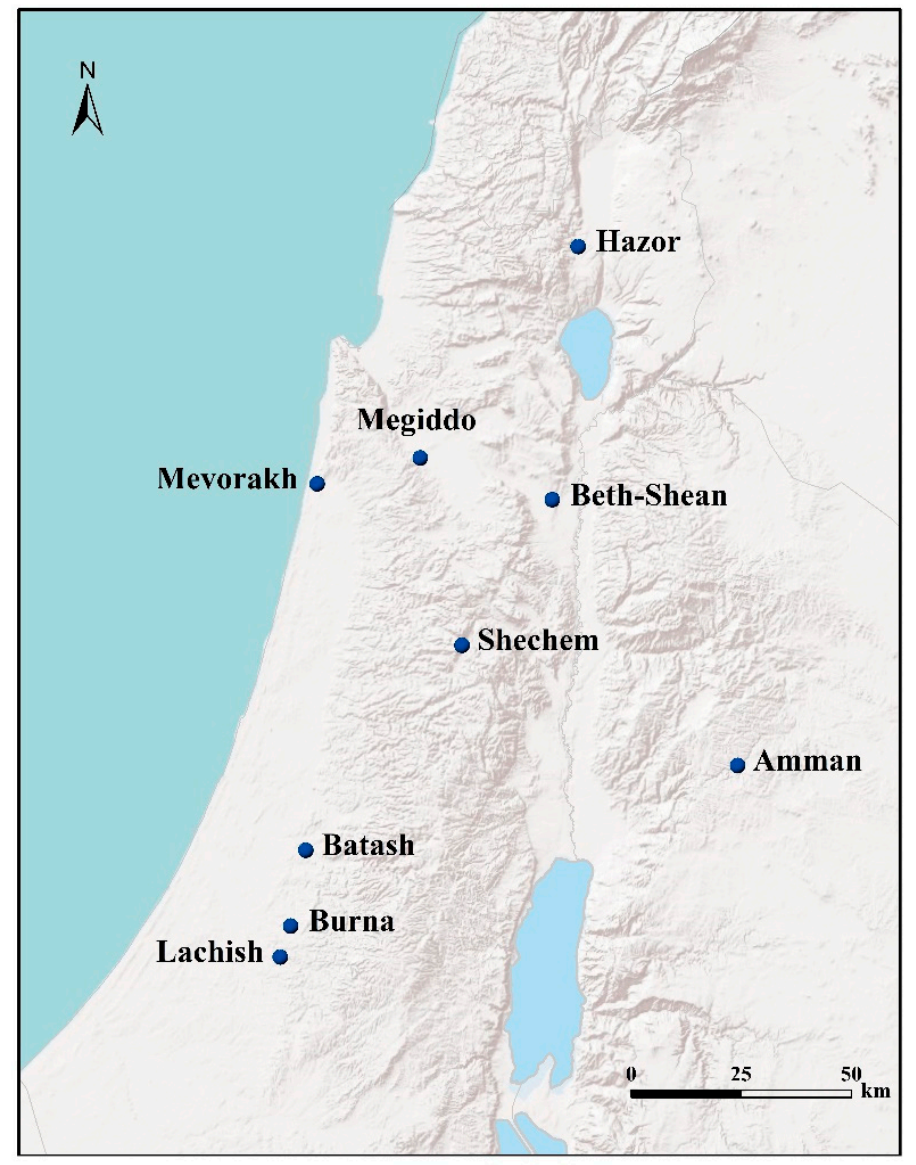

Figure 1. Late Bronze Age sites mentioned in the text (Prepared by H. Cohen-Klonymus). 
Emphasis in the survey and brief discussion below is placed upon sites with representative or particularly significant architectural or artifactual assemblages (for a more thorough survey of the Late Bronze Age temples, see Alpert-Nakhai 2001, pp. 125-52). The examination of the temple's plans reveals a great diversity, making it difficult to establish patterns and clear rules which governed their development during this period (see Figure 2 for several plans of Late Bronze Age temples). However, Mazar (1992b, p. 169) attempted to classify a number of these structures into homogenous categories displaying common characteristics (and see also Bunimovitz 2019, pp. 48-55). Some of the temples are unique in plan, and contemporary parallels cannot be easily pinpointed.

A. Open cult places-A good example was uncovered in Area F at Hazor. This is a paved plaza with a monolithic stone altar with depressions in the upper surface to drain the blood of the sacrificed animals.

B. Monumental symmetrical temples-the quintessential type of Canaanite temple used during the Late Bronze Age was actually a Middle Bronze tradition which continued in use into the Late Bronze Age. Such temples were found at Megiddo (temple 2048), Shechem, and Hazor (Areas $\mathrm{A}$ and $\mathrm{H}$ ), though with differences. Although these temples underwent substantial changes during the course of the Late Bronze Age, their main characteristics remained the same: they were long monumental and symmetrical buildings situated in the center of a sacred precinct. They were divided into two or three rooms-the forecourt, the main hall, and an inner sanctuary (often called "holy of holies"). In most cases, the main hall of the building was an almost-square broad room. A niche or stage for the placement of a statue of the god was often placed at the back end of the inner sanctuary. The walls of these temples were thick and their facades were sometimes flanked by two columns. A monumental structure was discovered in the center of Hazor's Upper City (Building 7050). This structure was interpreted as a palace by Amnon Ben-Tor (2006), though Sharon Zuckerman (2010), the co-director, preferred to identify it as a Temple. She based this interpretation on the prominent location of the structure, which is typical for temples of the period, as well as on the structure's plan, which includes only a small number of rooms which are surrounded the central hall. One of the back rooms had a basalt base (for a statue of a deity?). The large forecourt had an alter which was surrounded by animal bones, as well as evidence of votive vessels and metal figurines, which all testify to the cultic function of this structure. Finally, we must mention the abundant evidence for a "ruin cult" nearby in which the ruins of the Late Bronze Age temple were venerated by the Iron Age inhabitants of the city (Ben-Ami 2006). Two additional temples were found nearby Building 7050—-the Northern Temple and the Southern Temple (though not much was left of the latter). The "Northern Temple" was built in the northwest part of Area A and might have been a part of the ceremonial precinct. This "long Temple" was a large rectangular structure whose corners were oriented towards the compass and whose entrance faced the east. The courtyard was paved with plastered cobbles and its walls were probably lined with basalt orthostats. A plastered raised podium was located opposite the entrance and probably served as the main cultic locus (Zuckerman 2012, pp. 112-13). Hazor's Area H had a sequence of temples which began during the Middle Bronze Age and continued through the Late Bronze Age. At first, benches were added to the main hall, the inner sanctuary was closed from public view, and a stand for a cult statue was placed at one side. In the final stage, large basalt orthostats with lion images were placed to guard the temple's entrance (Figure 3), and additional well-cut orthostats were placed along the inner sides of the walls. The inner courtyard contained two stone altars surrounded by animal bones and ashes (Bunimovitz 2019, p. 51). Numerous cultic vessels and fragments of clay liver models were found nearby, as well as a basalt statue of a deity standing on a bull-possibly representing the storm god Baal. The Megiddo temple was also enclosed in a sacred compound and was comprised of a large forecourt surrounded by auxiliary rooms and storage spaces. At Shechem, a broad temple was built within a courtyard with a sacrificial altar and a huge standing stone (massebah). 

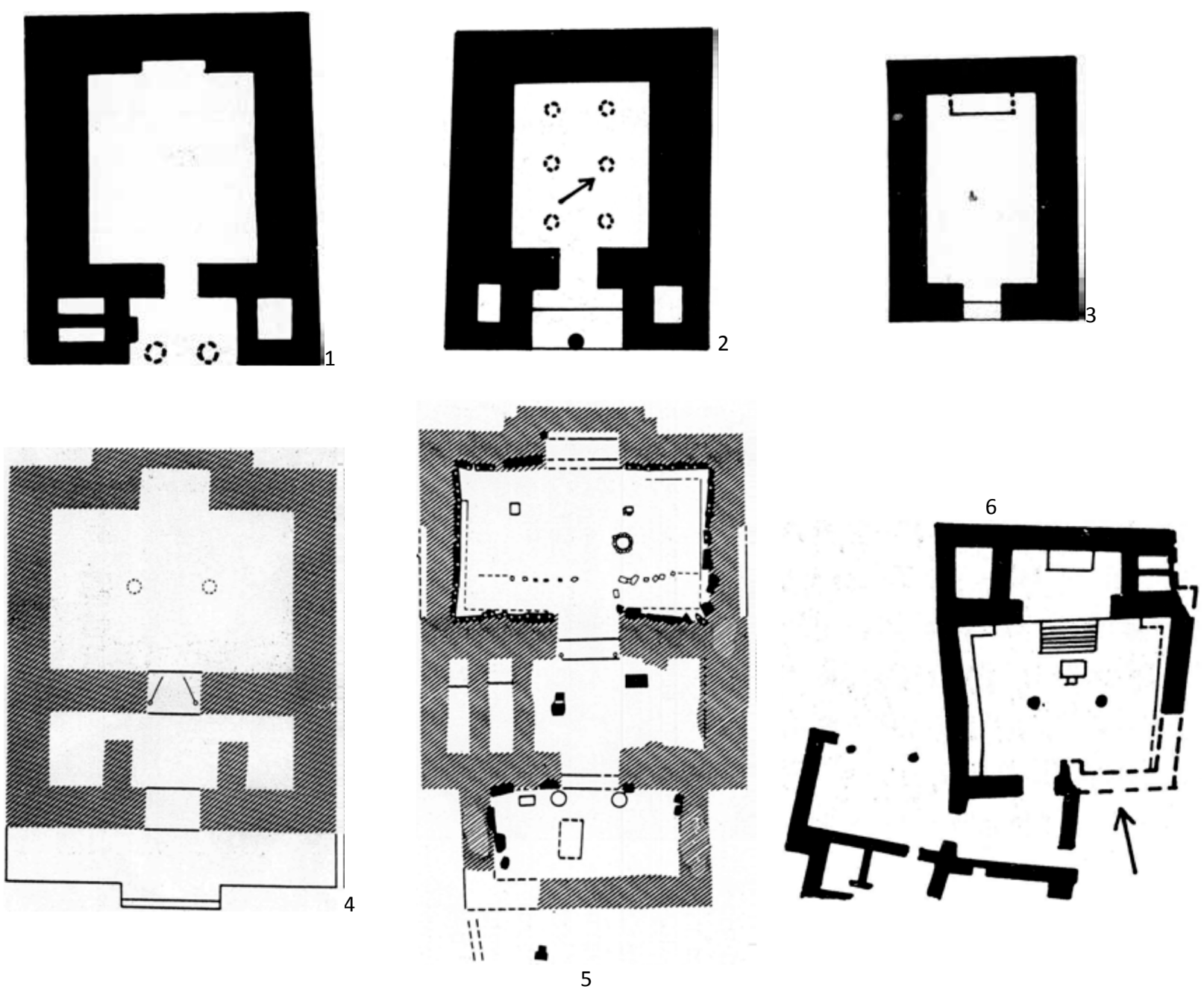

Figure 2. Cont. 


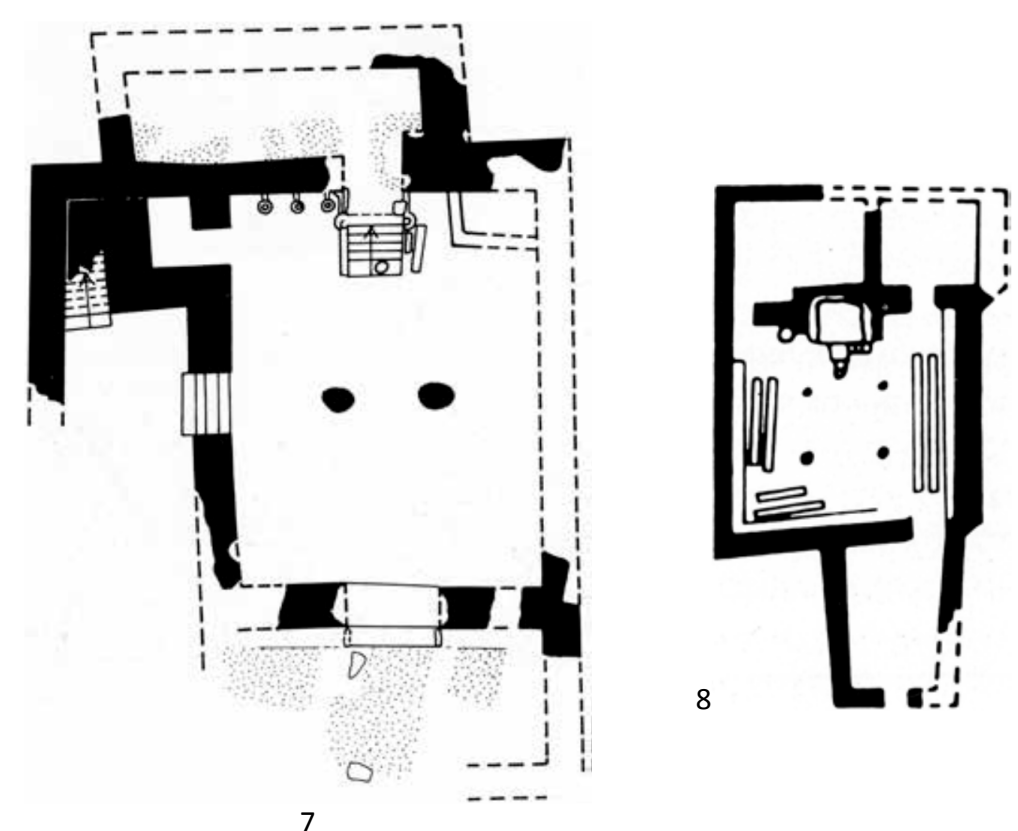

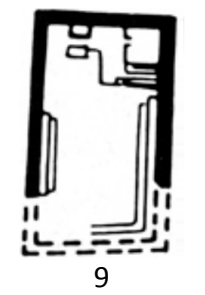

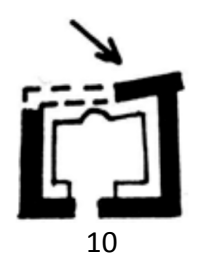

10

Figure 2. Plans of various Late Bronze Age Canaanite temples mentioned in the text (After Bunimovitz 2019: Figure 27. Originally published in Mazar 1992b; Courtesy of the Israel Exploration Society). 1. Megiddo str. VIII; 2. Shechem; 3. Hazor, "Northern Temple", Area A in the upper city; 4 . Hazor, Area H in the lower city, str. 3; 5. Hazor, Area H in the lower city, str. 1A; 6. Beth Shean, str. VI; 7. Lachish, “Acropolis Temple”, str. VI; 8. Lachish, Fosse Temple III; 9 . Tel Mevorakh; 10. Hazor, Stele Temple, Area $\mathrm{C}$ in the lower city. 


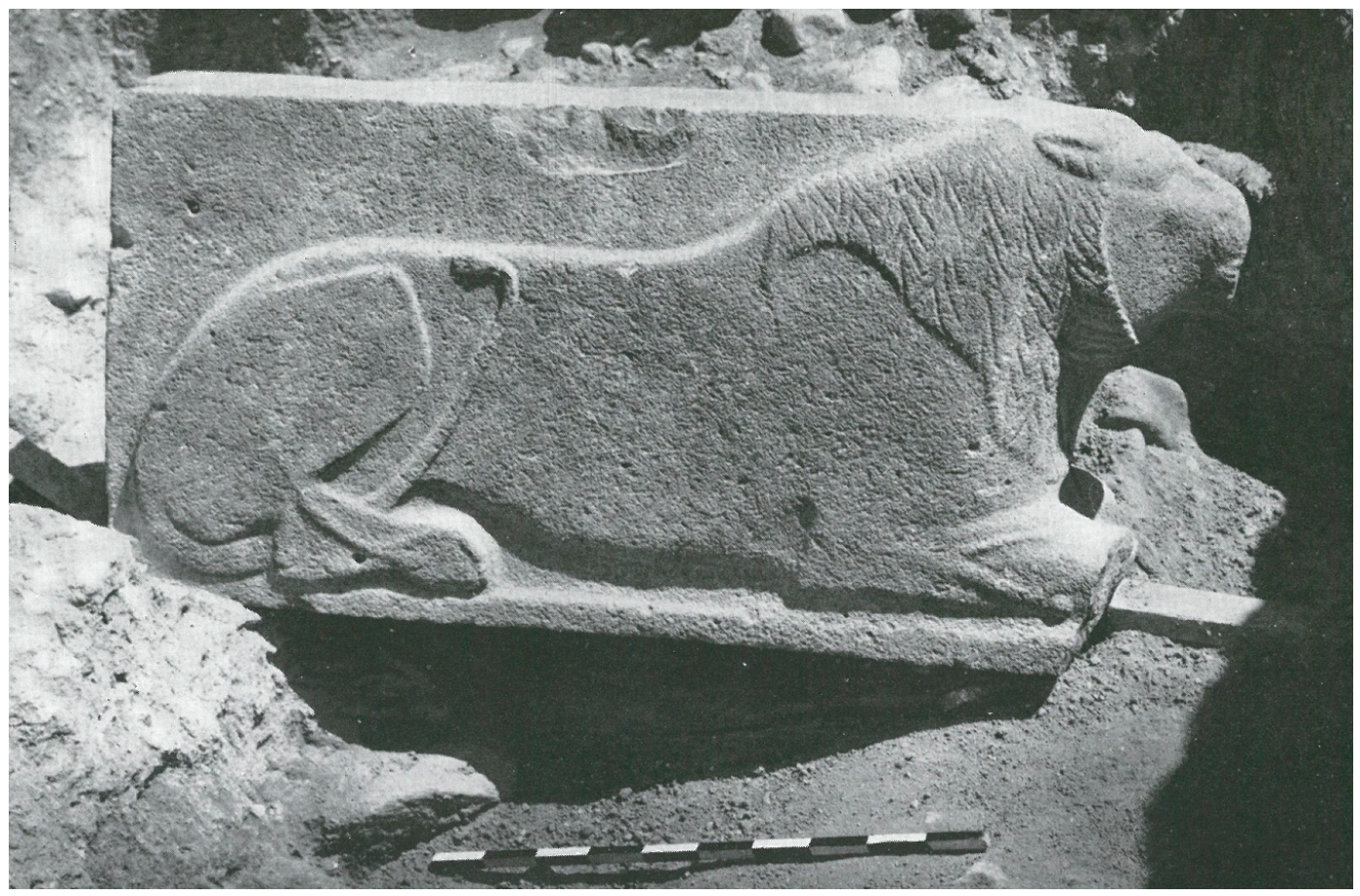

Figure 3. Basalt orthostat depicting a lion from the Area H temple at Hazor (From Yadin 1961: Plate CXX:2; courtesy of Amnon Ben-Tor and the Israel Exploration Society).

C. Temples with a raised inner sanctuary-the temples discovered in strata VIII-VII and VI at Beth-Shean and in stratum VI at Lachish exhibit many common characteristics, and thus form a separate category. The points of resemblance include the internal division of the building, the dimensions and proportions of the main hall, the elevated inner sanctuary (which was approached by a staircase and set in a separate architectural niche), and the Egyptian architectural elements incorporated into the buildings—especially the stone column capitals (Mazar 1992b, p. 173). The two successive Beth Shean temples and the Acropolis temple at Lachish - all dated to the thirteenth-early twelfth century BCE, when the Egyptian presence in the country was at its peak-had a combination of Canaanite concepts and Egyptian architectural decoration. Egyptian-styled architectural fragments were found at Beth-Shean, including stone friezes and papyrus-shaped capitals. The Acropolis temple at Lachish (Figure 4), located at the center of the mound, had two main columns with papyrus-shaped stone capitals in the Egyptian style, as well as decorative columns, some featuring Egyptian fluted shafts. Rare remains of interior wall painting in black, white, red, yellow, and blue are another reflection of Egyptian influence.

The architecture of these temples may reflect religious syncretism, also suggested by some cultic art objects which combined Egyptian and Canaanite motifs (e.g., Bunimovitz 2019, p. 54; Mullins 2012). Mazar (1992b, p. 177) wrote that, whereas the temples at Beth-Shean were founded in the center of the Egyptian government and were most certainly used by Egyptian soldiers, officials, and mercenaries, the temple at Lachish was erected on the acropolis of a royal Canaanite city and should be regarded as a reflection of Egyptian influence on Canaanite architecture and cult. 


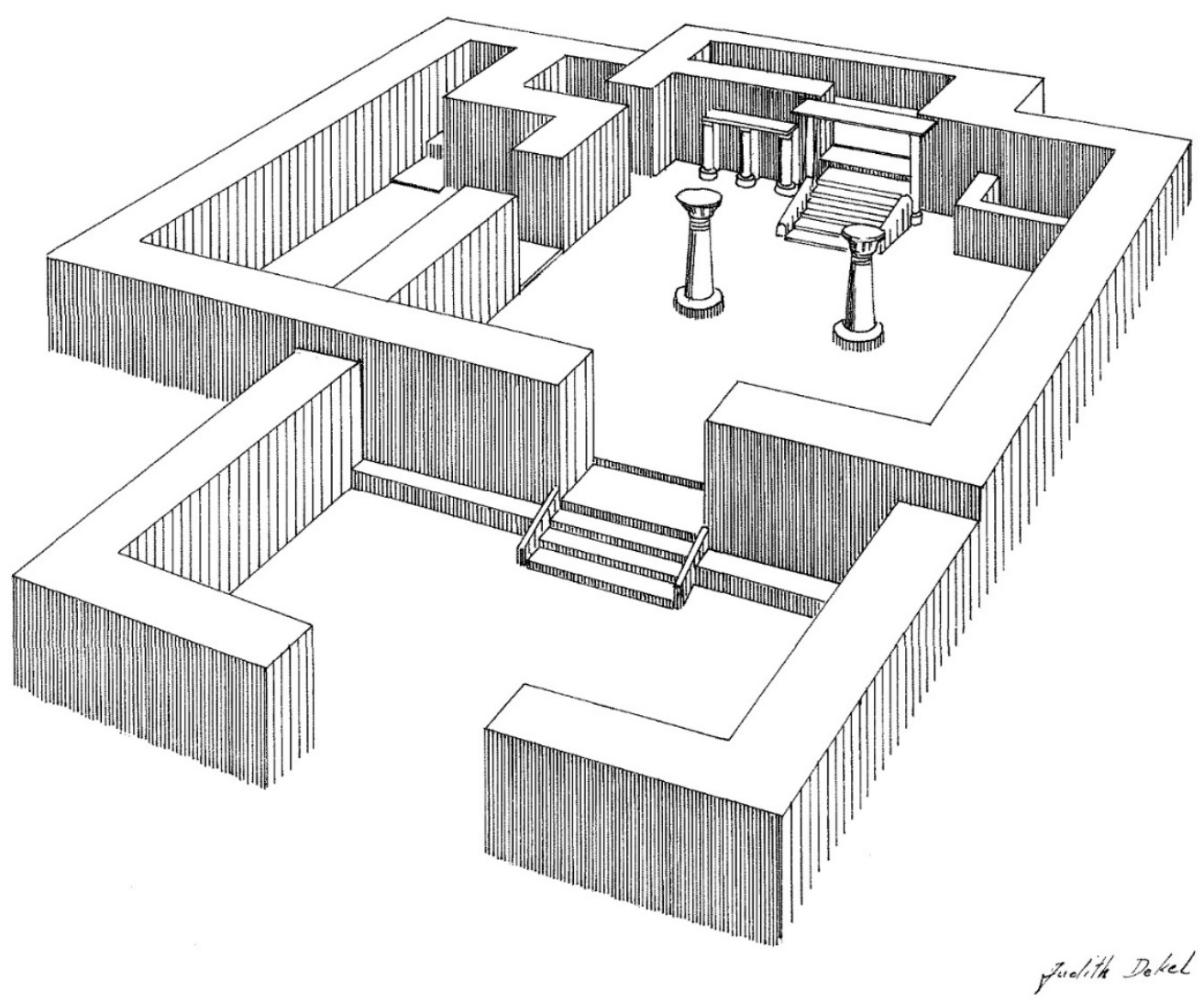

Figure 4. Suggested reconstruction of the main Acropolis Temple Complex at Lachish (From Ussishkin 2004: Figure 6:4; courtesy of the Institute of Archaeology of Tel Aviv University).

D. Temples with indirect entrances and irregular plans-This group of Late Bronze temples is characterized by an indirect entrance and a plan which lacks any attempt at symmetry or clear architectural rules and principles. In these temples, one could not see the inner sanctuary from the entrance; they had benches along the walls, columns supporting the ceilings, and an elevated inner sanctuary. Additional rooms were built for storage around the temple (Mazar 1992b, p. 182). This group includes the succession of Fosse temples at Lachish, the Tel Mevorakh road sanctuary, one of the Beth-Shean temples (level R2 which had a trapezoid inner sanctuary; see Figure 5), and several other buildings whose identification as temples is not certain (Mazar 1992b, p. 177). The excavators argued that the Lachish Fosse temples served nomads or shepherds, since they were built outside of the settlement. Bunimovitz (2019) suggested that these temples may represent foreign elements who settled in Canaan. Bietak (2002) suggested that funerary ceremonies were conducted within them, as they resembled Egyptian temples with similar functions. Although situated in the northern reaches of Canaan, we should also make note of the Late Bronze Age sequence of Temples at Kamid el-Loz which had irregular plans (DePietro 2012, p. 59). This structure gained rooms and surface area as time went on, so that by the end of its use, the original three-room construction had become a veritable double temple. This constant enlargement may be seen in connection with a continuous increase in importance of the institution (Heinz and kulemann-Ossen 2014).

E. Small temples with direct access-a small number of Late Bronze Age temples cannot be assigned to any of the above groups (Mazar 1992a, p. 253). These include the temple in Area C at Hazor and perhaps the temple at Timna, to name a few (the identification of others as temples, like the structure discovered in the 'Amman airport, were not universally accepted). The small temple in Area $\mathrm{C}$ in Hazor had benches along its interior walls and a cultic focal point near the entrance. Its final stage contained eleven basalt stele which stood in a line (Figure 6). The middle one had a 
relief of a pair of hands pointing upwards with a crescent containing a disc above them. A statue of a man sitting on a chair with an upside-down crescent was discovered near the stele. These elements were explained by the excavator Yigael Yadin as representing the moon god and his consort. In addition, a small orthostat with a crouched lion was found, as well as another basalt plate used for offerings. It would seem that this temple served the residential quarters nearby.

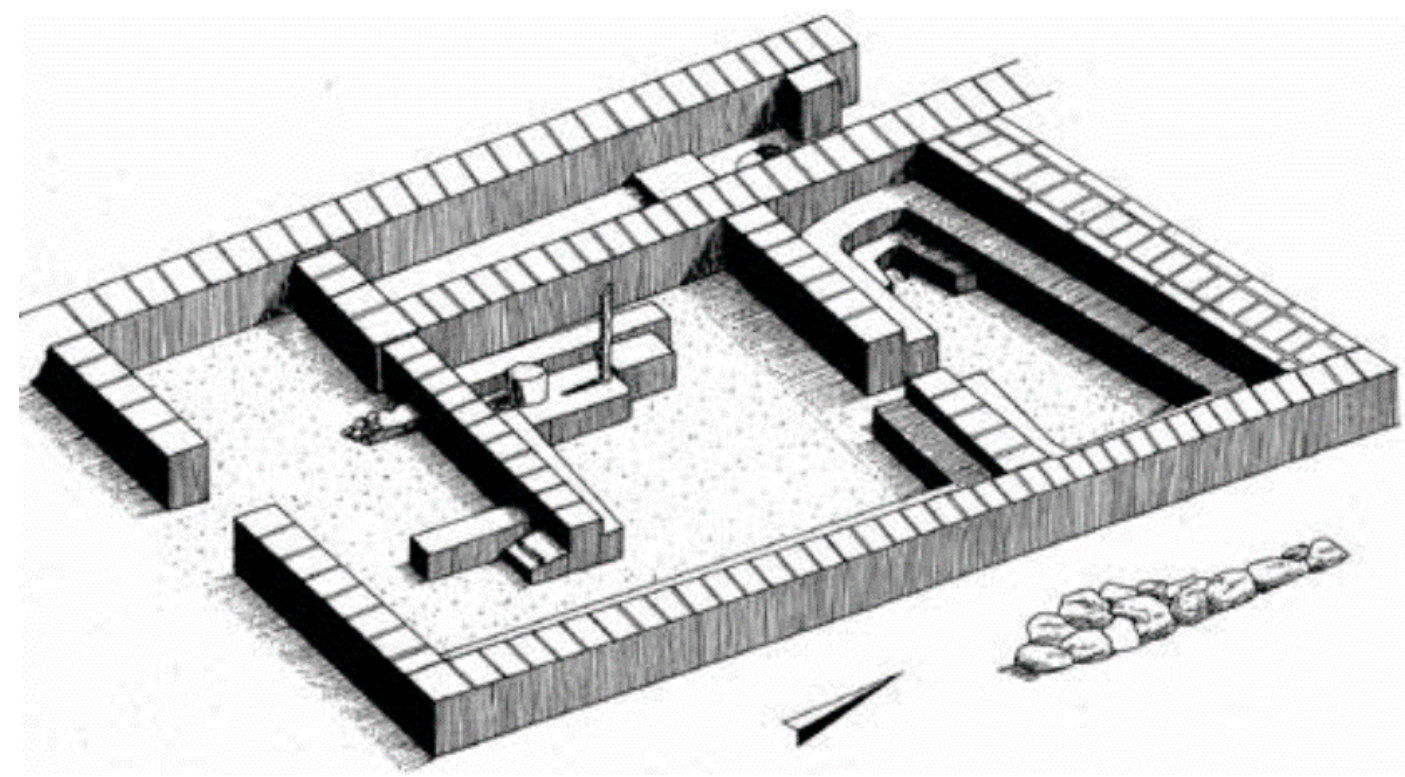

Figure 5. Isometric view of the Level R2 temple at Beth-Shean (From Mullins and Mazar 2007: Figure 3.19; courtesy of Amihai Mazar and the Israel Exploration Society).

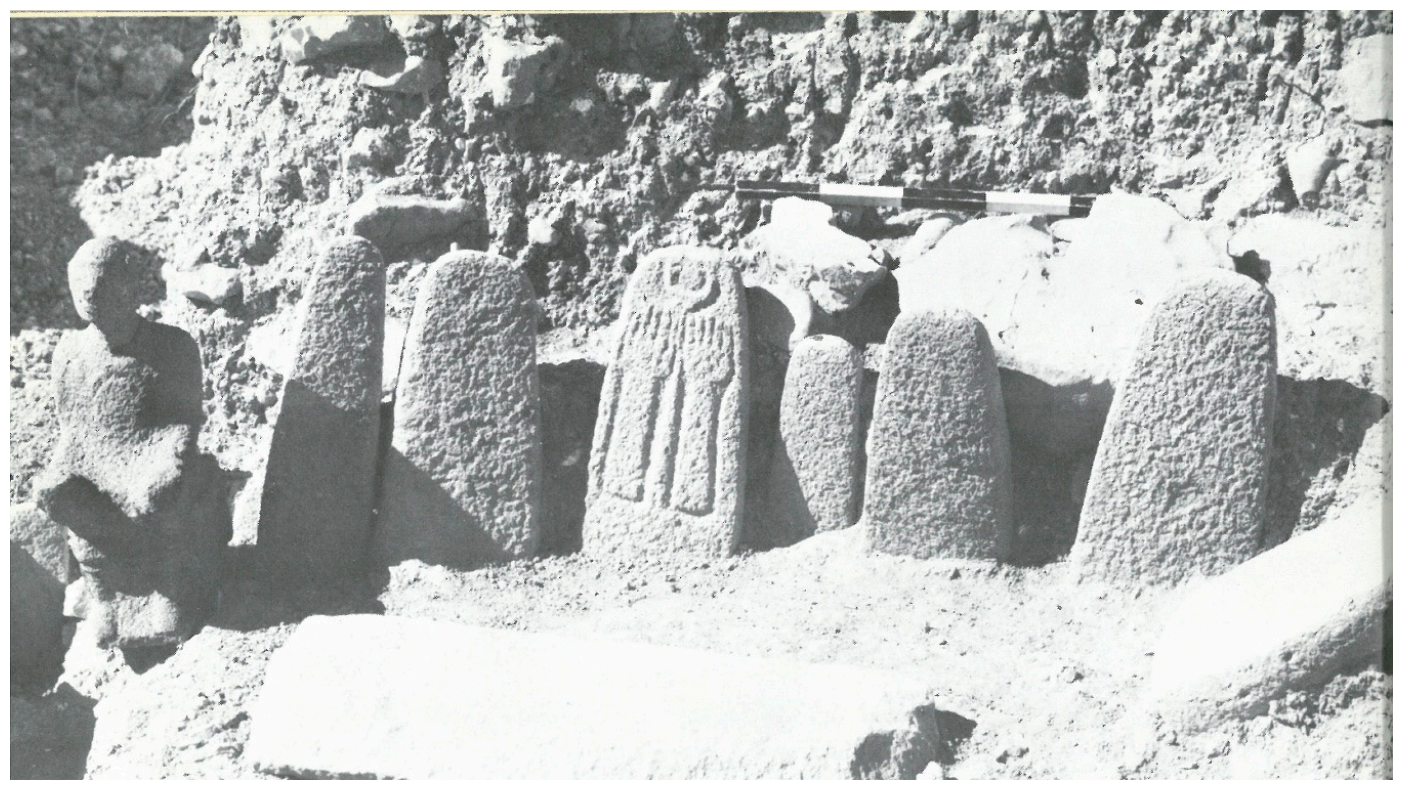

Figure 6. Cultic objects from the "Stelae Temple" in Area C at Hazor (From Yadin 1975: Page 46; courtesy of Amnon Ben-Tor and the Israel Exploration Society).

The temple at Timna in the Arava was erected as part of the Egyptian copper mining and smelting operation. It consisted of a broad room; the entrance was located in the middle of the eastern wall and the inner sanctuary was opposite it on a raised platform. Stone stelae, some with relief decorations depicting the head of Hathor, were placed in the temple. The varied finds in the temple included 
small Egyptian offerings such as seals, jewelry, and art objects. The Egyptians dedicated this temple to Hathor, the patroness of the mine. Mazar (1992b, p. 182) claimed that there is no close parallel to the Timna temple in the Egyptian architectural tradition.

Mazar (1992a, p. 257) proposed that the variations in religious architecture in Late Bronze Age Canaan may reflect not only the complexity of religious practices during that time, but also demographic heterogeneity. Alpert-Nakhai (2001, p. 122) wrote that in the Late Bronze Age, Canaan was increasingly the subject of external imperial strategies. Although northern sites such as Hazor continued to reflect Syrian influences over time, Egyptian control over the southern regions increased and so did the number of Egypto-Canaanite temples designed to serve Egyptian imperial needs (see also Koch 2018, pp. 101-16 and DePietro 2012). The Egyptian presence thus had a strong influence not only on the political and organizational framework in Canaan, but also on its demography and social and religious horizons (for more about strong Egyptian influences on Canaanite burial practices during this period, see Gonen 1992).

Shai et al. (2015) examined the artifacts found within a recently excavated temple at Tel Burna in order to better understand the cultic activities and rituals which took place within the temples. Samet (2017, p. 152) noted that a surprising feature of the ceramic assemblage in Late Bronze Age temples is that vessels made especially to be used in cults (i.e., miniatures, decorated stands, decorated goblets, chalices, etc.) form a very small part of the ceramic assemblage. Rather, the ceramic assemblage is dominated by serving vessels, indicating that food and drink consumption was the predominant activity. In other words, votive activity (common during the previous Middle Bronze Age) was replaced by commensality in Late Bronze temples.

Samet (2017, p. 159) suggested that the Canaanite elite residing in the palaces suffered a sharp decrease in its political power following the Egyptian conquest. While competitive dedications did persist, the popular ceramic dedications were replaced by evidence of large-scale feasting, in which food and drink were consumed. These were likely means to rally popular support of their rulership in difficult times, which could only be answered by placing a heavy burden on the Canaanite commoners. The small number of storage jars and cooking pots indicates that storage was not an important feature in the temples. This may mean that participants in these religious feasts were expected to bring foodstuffs and beverages with them (Samet 2017, p. 271). It seems that the dedication of foodstuffs replaced the dedication of cultic vessels. This may indicate the important social role of the Late Bronze temples.

\section{Figurines}

Small clay figurines which depict naked women were a popular Canaanite cultic item during the Late Bronze Age. These figurines were produced by pressing clay into an open cast (Figure 7). The women were usually depicted holding lotus flowers or their breasts. Their hairstyle resembled that of the Egyptian Goddess Hathor (see Cornelius 2004 for a possible typological grouping of these figurines). Most of these figurines were discovered in domestic contexts (the ones found in tombs should also be understood as 'domestic' and continuing their same function). They were usually found in secondary contexts, recently leading Levavi-Eilat (2014) to the conclusion that they were not ceremoniously disposed of, but may have been intentionally broken during apotropaic rituals. 


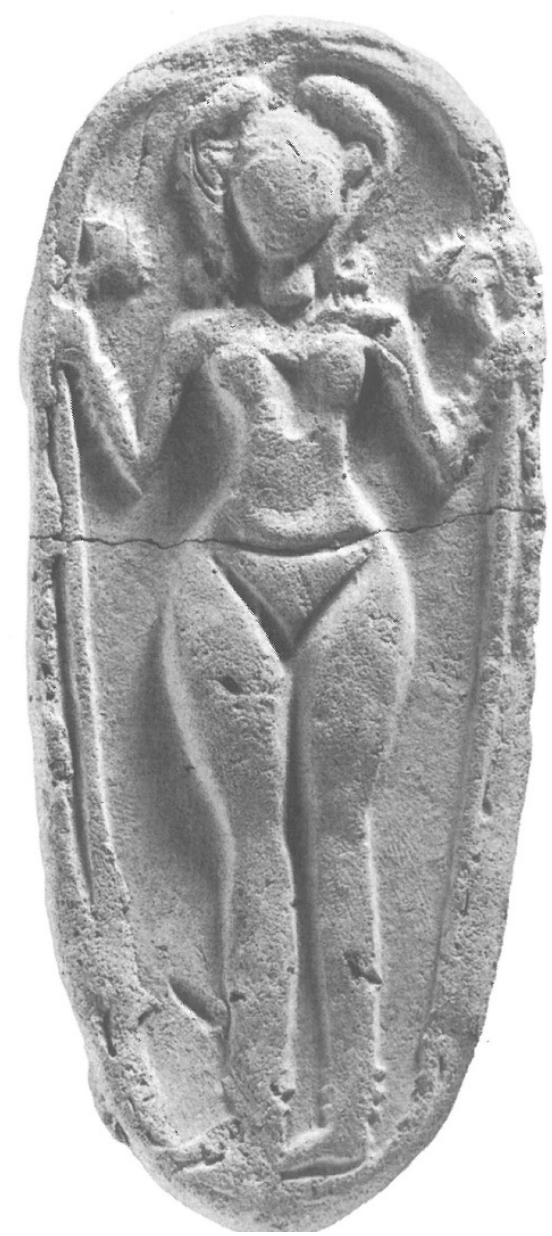

Figure 7. Canaanite Figurine plaque of a naked goddess from Tel Batash (From Mazar 2006: Photo 104; courtesy of Amihai Mazar and the Institute of Archaeology, The Hebrew University of Jerusalem).

These figurines are usually assumed to be representations of one of the Canaanite goddesses of sex and fertility-Asherah, Anat, or Astarte. Within one individual deity, this goddess perhaps combined the powers of mother earth, giving birth to humans and animals, nourishing them and helping them flourish. In any case, it is not only difficult to determine which goddess is depicted, but also the function of the figurines within the local cult practices (Bunimovitz 2019, p. 56). Hess (2007, p. 138) suggested that the female deity terra-cotta forms demonstrate a popularization and privatization of cultic worship. Additional figurines were made of metal. The most popular subjects were the young warrior god, most probably Baal, striding and holding weapons. Other popular figurines include enthroned male gods, identified as El, dressed in a long mantle (See example from Hazor in Figure 8).

The Canaanite goddesses were also portrayed on plaques or triangular gold pendants. Sometimes, the full body of the goddess is shown, while in other cases, only the head and fertility organs are featured. The goddess is usually depicted riding a horse, though there are several representations of a naked goddess standing on a lion. A variation of this figure appears on a large gold sheet found in the Acropolis temple at Lachish (Figure 9). This is an exceptional work of art illustrating the cultural and religious interchange between Canaan and Egypt. 


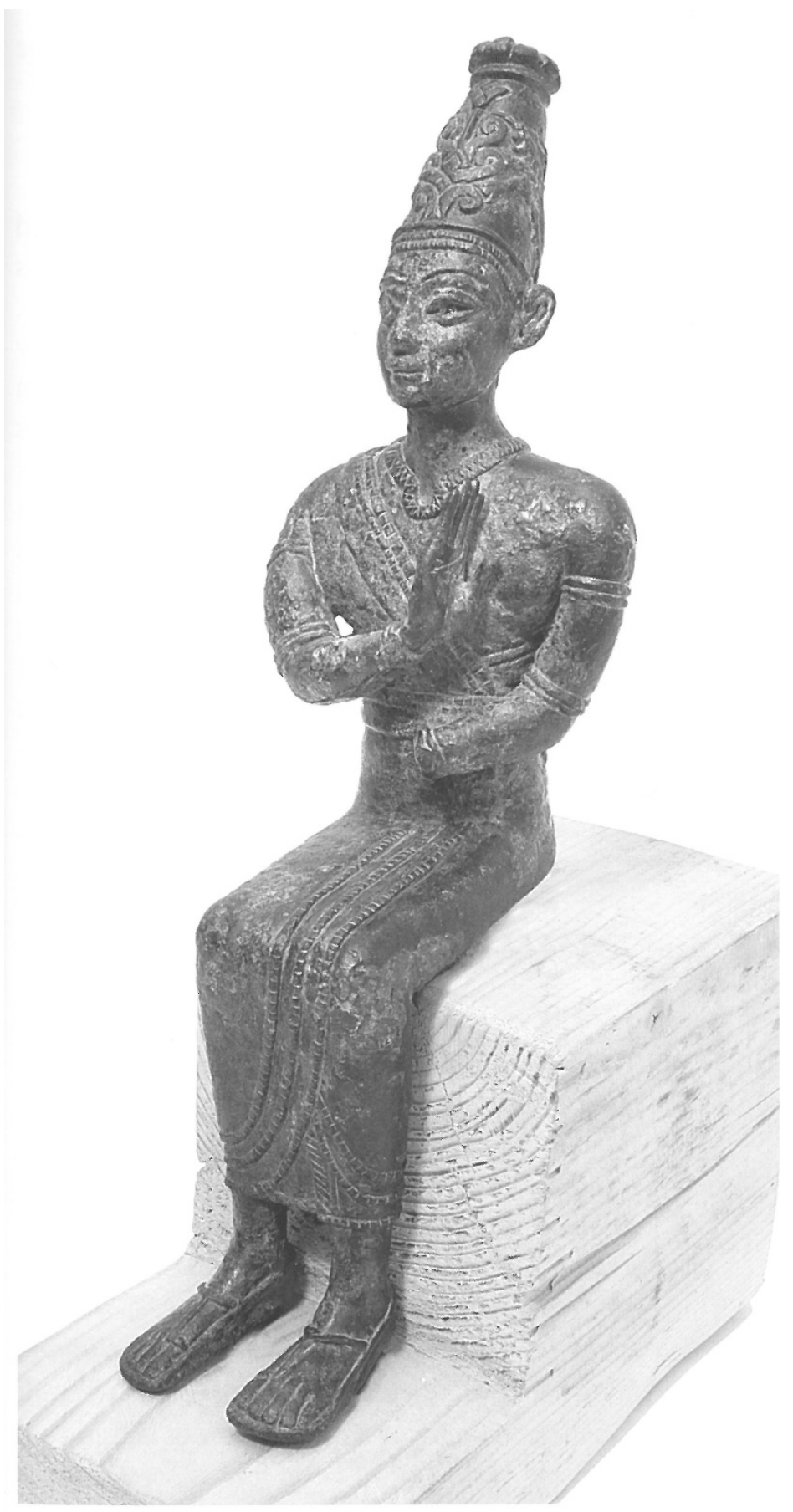

Figure 8. Enthroned male god figurine from Hazor (From Ornan 2017: Photo 10.6; courtesy of Amnon Ben-Tor and the Israel Exploration Society).

The figure of the goddess is simply, but rather gracefully, designed. She is shown in profile wearing a huge crown, which seems to be composed of two ostrich feathers flanked by two pairs of cow horns, all set onto a pair of ram's horns. It resembles the feather crown of Lower Egypt called the anedtj-crown, which is composed of several elements. The goddess is standing on a horse and holding two lotus flowers. The Lachish goddess, as characterized by nudity, her posture, a Hathor wig, the crown, and with attributes such as lotus flowers, is known from Canaan, as well as from Egypt, where she is identified as Qudshu, and related to the cult of fertility and love. Egyptian elements are evident in other parts of the plaque as well. In any case, the mythological personality of Qudshu, and her 
equation with Asherah, Astarte, or Anat, is rather elusive in Canaan, due to the lack of literary and epigraphic sources on the Canaanite pantheon and the difficulty in clearly defining the functions and personalities of Canaanite and Egyptian divinities (Clamer 2004, pp. 1314-20).

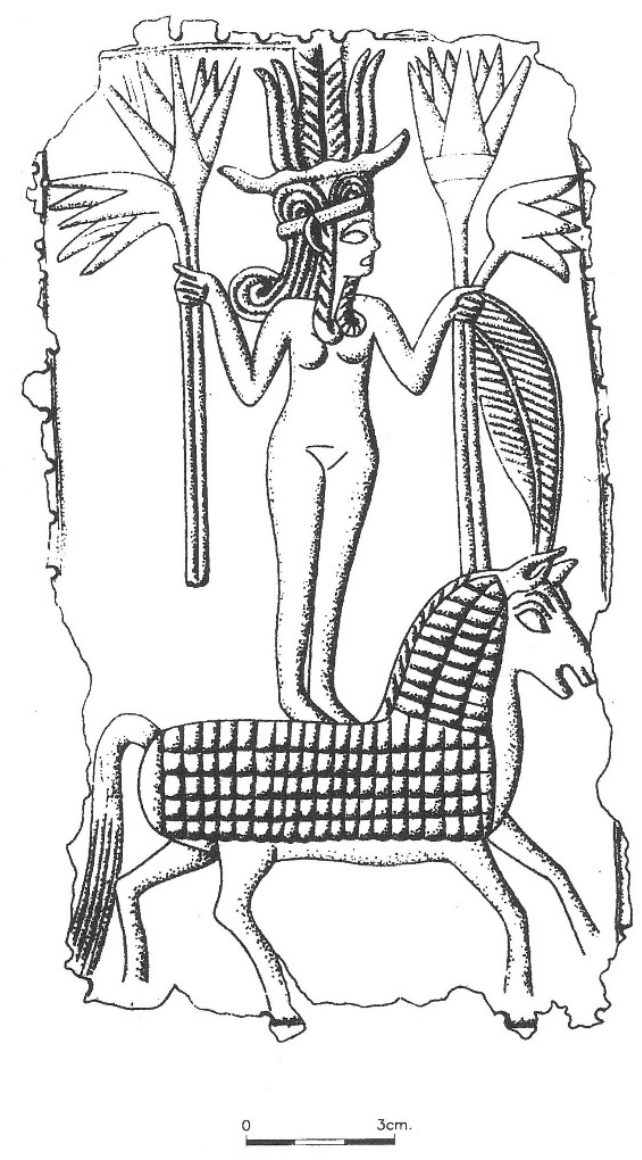

Figure 9. Canaanite Goddess depicted on a gold plaque found in the Lachish Acropolis temple ((From Clamer 2004: Figure 21:21; courtesy of the Institute of Archaeology of Tel Aviv University).).

Examples of painted vessels with a highly stylized palm tree, flanked by caprids, have been found in many Late Bronze contexts (Bunimovitz 2019, p. 62). In some representations, the tree is replaced by a pubic triangle, reflecting the association of the tree with a goddess and fertility. Similar motifs have been identified on contemporary cultic stands. These stands themselves may be stylized versions of the tree of life, one of the oldest and most widespread motifs in ancient Near East art and iconography.

\section{Lamp-and-Bowl Deposits}

Another phenomenon, usually associated with popular cults, are groups of vessels, mostly new bowls and lamps, which were deposited under the foundations of various structures (Figure 10). Bunimovitz and Zimhoni (1993) noted that these were found mostly in the areas with a strong Egyptian influence and connected this practice to a similar one which is known from contemporary Egyptian foundation rituals. The deposits found in Egypt included small versions of real vessels, as well as materials which were used to construct the building. The phenomenon therefore hints to an Egyptian cultural influence, though the vessels were local (for a slightly different view, see DePietro 2012, pp. 99-124). 


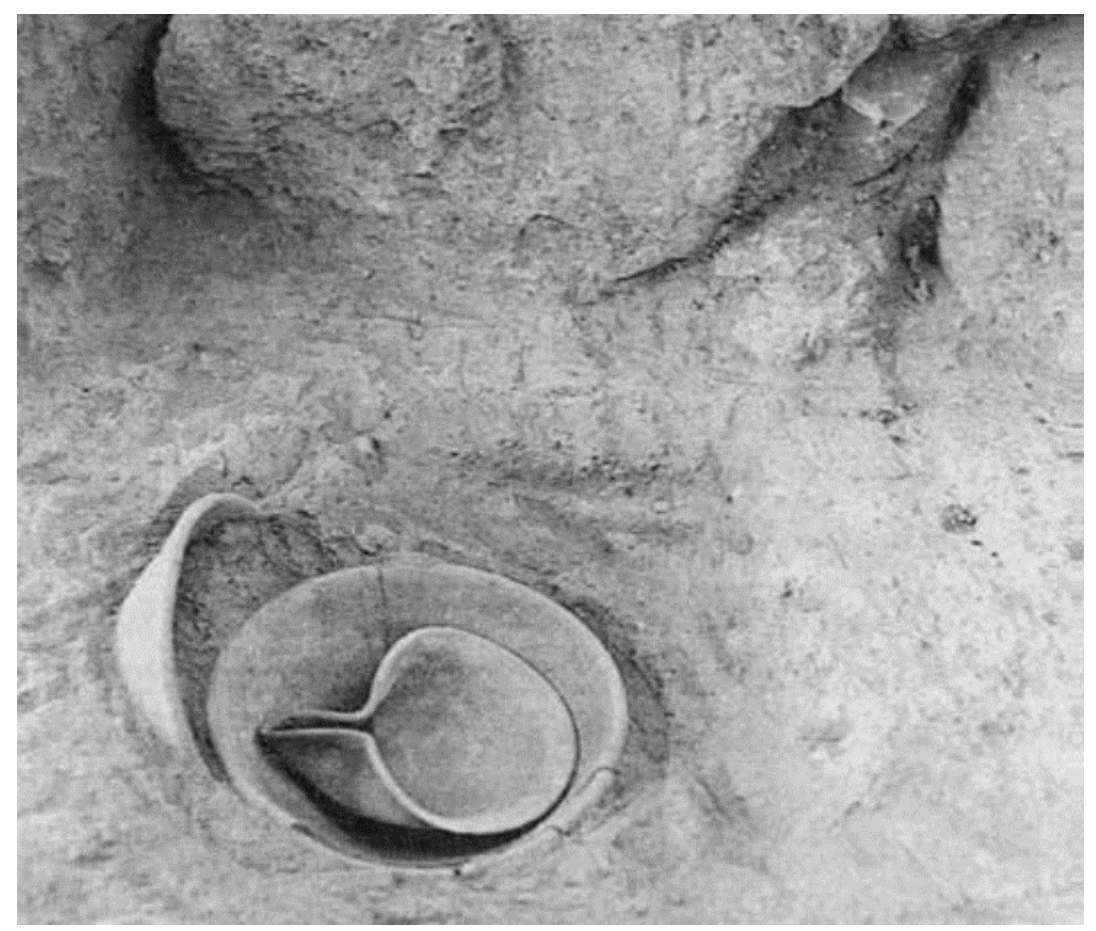

Figure 10. Lamp-and-bowl foundation deposit from Area S (Level VI) at Lachish (From Bunimovitz and Zimhoni 2004: Figure 19:60; courtesy of the Institute of Archaeology of Tel Aviv University).

\section{Summary}

Both the written and archaeological evidence for cultic activities during the Late Bronze Age is abundant. The written texts, and the variety of temples, figurines, and other cultic paraphernalia, demonstrate the openness of the Canaanite religion during the Late Bronze Age. Different regions and settlements may have worshipped different sets of gods and goddesses. The cultic activities seem to have been influenced by neighboring powers, such as the Hittites and especially the Egyptians and their pantheon of gods and symbolism. In fact, there seems to have been a syncretism and mix of symbolisms between the Canaanite and Egyptians-especially towards the end of the period. The long-lasting Canaanite religious traditions and cult practices persevered despite the collapse of the Canaanite city-state organization at the end of the Late Bronze Age, and had a great influence (in both belief systems and cultic practices) on the developing nation states and cultures during the Iron Age.

Funding: This research received no external funding.

Acknowledgments: I would like to thank Avraham Faust for the invitation to contribute this article to this special issue on Archaeology and Israelite Religion. Thanks also to the anonymous reviewer whose thoughtful comments helped to improve the paper.

Conflicts of Interest: The author declares no conflict of interest.

\section{References}

Alpert-Nakhai, Beth. 2001. Archaeology and the Religions of Canaan and Israel. Boston: American Schools of Oriental Research.

Ben-Ami, Doron. 2006. Early Iron Age Cult Places. New Evidence from Tel Hazor. Tel Aviv 33: 121-33. [CrossRef] Ben-Tor, Amnon. 2006. Ceremonial Palace, not a Temple. Biblical Archaeology Review 32: 8, 78-79.

Bietak, Manfred. 2002. The Function and Some Architectural Roots of the Fosse Temple at Lachish. In Beer-Sheva XV. Studies in Archaeology and Related Disciplines. Aharon Kempinski Volume. Edited by Shmuel Ahituv and Eliezer Oren. Beer Sheva: Department of Bible and Ancient Near East. 
Bunimovitz, Shlomo. 1995. On the Edge of Empires—Late Bronze Age (1500-1200 BCE). In The Archaeology of Society in the Holy Land. Edited by Thomas E. Levy. London: Continuum, pp. 320-29.

Bunimovitz, Shlomo. 2019. The Late Bronze Age. In Introduction to the Archaeology of the Land of Israel from the Neolithic to Alexander's Conquests. Edited by Avraham Faust and Hayah Katz. Ra'anana: The Open University of Israel. (In Hebrew)

Bunimovitz, Shlomo, and Orna Zimhoni. 1993. “Lamp-and-Bowl” Foundation Deposits in Canaan. Israel Exploration Journal 43: 99-125.

Bunimovitz, Shlomo, and Orna Zimhoni. 2004. Appendix: Lamp-and-Bowl Foundation Deposits in Areas P and S. In The Renewed Archaeological Excavations at Lachish (1973-1994), Volume III. Edited by David Ussishkin. Tel Aviv: Emery and Clair Yass Publication in Archaeology, pp. 1147-54.

Clamer, Christa. 2004. The Pottery and Artefacts from the Level VI Temple. In The Renewed Archaeological Excavations at Lachish (1973-1994), Volume III. Edited by David Ussishkin. Tel Aviv: Emery and Clair Yass Publication in Archaeology, pp. 1288-325.

Cornelius, Sakkie. 2004. A Preliminary Typology for the Female Plaques Figurines and their Value for the Religion of Ancient Palestine and Jordan. Journal of Northwest Semitic Languages 30: 21-39.

Cross, Frank Moore. 1998. From Epic to Canon: History and Literature in Ancient Israel. Baltimore: The Johns Hopkins University Press.

Day, John. 1992. Canaan, Religion of. In The Anchor Bible Dictionary. Edited by David N. Freedman. New York: Doubleday, pp. 831-37.

DePietro, Dana D. 2012. Piety, Practice and Politics: Ritual and Agency in the Late Bronze Southern Levant. Ph.D. dissertation, U.C. Berkeley, Berkeley, CA, USA.

Faust, Avraham. 2010. The Archaeology of the Israelite Cult: Questioning the Consensus. Bulletin of the American Schools of Oriental Research 360: 23-35. [CrossRef]

Faust, Avraham. 2019. Israelite Temples: Where Was Israelite Cult Not Practiced and Why. Religions 10: 106. [CrossRef]

Finkelstein, Israel. 1996. The Territorial-Political System of Canaan in the Late Bronze Age. Ugarit-Forschungen 28: 221-55.

Gonen, Rivka. 1992. Burial Patterns and Cultural Diversity in Late Bronze Age Canaan. Winona Lake: Eisenbrauns.

Goren, Yuval, Israel Finkelstein, and Nadav Na'aman, eds. 2004. Inscribed in Clay: Provenance Study of the Amarna Tablets and Other Ancient Near Eastern Texts. Tel Aviv: Emery and Clair Yass Publications in Archaeology.

Heinz, Marlies, and Sabina kulemann-Ossen. 2014. Chapter 35. The Northern Levant (Lebanon) during the Late Bronze Age. In The Oxford Handbook of the Archaeology of the Levant C. 8000-332 BCE. Edited by Margreet L. Steiner and Ann E. Killebrew. Oxford: Oxford University Press, pp. 524-40.

Hess, Richard S. 2007. Israelite Religions: An Archaeological and Biblical Survey. Grand Rapids: Baker Academics.

Koch, Ido. 2018. The Shadow of Egypt: Colonial Encounters in Southwest Canaan during the Late Bronze Age and Early Iron Age. Jerusalem: Yad Yitzhak Ben-Zvi. (In Hebrew)

Levavi-Eilat, Sarah. 2014. Discarded Women: A Contextual Study of the use of Canaanite Terracotta Plaque Figurines. Master's thesis, Tel Aviv University, Tel Aviv, Israel. (In Hebrew)

Lev-Tov, Justin S. E., and Edward F. Maher. 2001. Food in Late Bronze Age Funerary Offerings: Faunal Evidence from Tomb I at Tell Dothan. Palestine Exploration Quarterly 133: 91-110. [CrossRef]

Mazar, Amihai. 1992a. Archaeology of the Land of the Bible 10,000-586 B.C.E.. New York: Doubleday.

Mazar, Amihai. 1992b. Temples of the Middle and Late Bronze Ages and the Iron Age. In The Architecture of Ancient Israel: From the Prehistoric to the Persian Periods. Edited by Aharon Kempinski, Ronnie Reich and Hannah Katzenstein. Jerusalem: Israel Exploration Society, pp. 161-87.

Mazar, Amihai. 2006. Clay Figurines and a Zoomorphic Vessel. In Timna (Tel Batash) III: The Finds from the Second Millennium BCE (Qedem 45). Edited by Nava Panitz-Cohen and Amihai Mazar. Jerusalem: Institute of Archaeology, The Hebrew University of Jerusalem, pp. 251-54.

Moran, William L., ed. 1992. The Amarna Letters. Baltimore: Johns Hopkins University Press.

Mullins, Robert A. 2012. The Late Bronze and Iron Age Temples at Beth-Shean. In Temple Building and Temple Cult: Architecture and Cultic Paraphernalia of Temples in the Levent (2.-1. Mill. B.C.E.). Edited by Jens Kamlah. Wiesbaden: Harrassowitz Verlag, pp. 127-57. 
Mullins, Robert A., and Amihai Mazar. 2007. The Stratigraphy and Architecture of the Middle and Late Bronze Ages: Strata R-5-R-1A. In Excavations at Tel Beth-Shean 1989-1996, Volume II: The Middle and Late Bronze Strata in Area R. Edited by Amihai Mazar and Robert Mullins. Jerusalem: Israel Exploration Society, pp. 39-199.

Ornan, Tallay. 2017. Metal Statuary. In Hazor VII (The Selz Foundation Hazor Excavations in Memory of Yigael Yadin): The 1990-2012 Excavations. The Bronze Age. Edited by Amnon Ben-Tor, Sharon Zuckerman, Shlomit Bechar and Debora Sandhaus. Jerusalem: Israel Exploration Society and the Institute of Archaeology, The Hebrew University of Jerusalem, pp. 514-18.

Samet, Inbal. 2017. Pottery Consumption and International Trade in Middle Bronze Age Kabri and Other Canaanite Palatial Polities. Ph.D. dissertation, University of Haifa, Haifa, Israel.

Shai, Itzhaq, Chris McKinny, and Joe Uziel. 2015. Late Bronze Age Cultic Activity in Ancient Canaan: A View from Tel Burna. Bulletin of the American Schools of Oriental Research 374: 115-33. [CrossRef]

Smith, Mark S. 2001. The Origins of Biblical Monotheism. Oxford: Oxford University Press.

Smith, Mark S. 2007. Recent Study of Israelite Religion in Light of the Ugaritic Texts. In Ugarit at Seventy-Five. Edited by K. Lawson Younger Jr. Winona Lake: Eisenbrauns, pp. 1-25.

Ussishkin, David. 2004. Area P: The Level VI Temple. In The Renewed Archaeological Excavations at Lachish (1973-1994), Volume I. Edited by David Ussishkin. Tel Aviv: Emery and Clair Yass Publications in Archaeology, pp. 215-81.

Van der Toorn, Karel, Bob Becking, and Pieter W. Van der Horst, eds. 1999. Dictionary of Deities and Demons in the Bible. Leiden: Brill Publishing.

Yadin, Yigal. 1961. Hazor III-IV. Jerusalem: The Hebrew University.

Yadin, Yigal. 1975. Hazor: The Rediscovery of a Great Citadel of the Bible. New York: Random House.

Yon, Marguerite. 2006. The City of Ugarit at Tell Ras Shamra. Winona Lake: Eisenbrauns.

Zuckerman, Sharon. 2010. “The City, Its Gods Will Return There ... ". Towards an Alternative Interpretation of Hazor's Acropolis in the Late Bronze Age. Journal of Near Eastern Studies 69: 163-78. [CrossRef]

Zuckerman, Sharon. 2012. The Temples of Canaanite Hazor. In Temple Building and Temple Cult: Architecture and Cultic Paraphernalia of Temples in the Levent (2.-1. Mill. B.C.E.). Edited by Jens Kamlah. Wiesbaden: Harrassowitz Verlag, pp. 99-125.

(C) 2019 by the author. Licensee MDPI, Basel, Switzerland. This article is an open access article distributed under the terms and conditions of the Creative Commons Attribution (CC BY) license (http://creativecommons.org/licenses/by/4.0/). 